\author{
Anna Kostecka-Sadowa \\ Polska Akademia Nauk w Krakowie \\ Instytut Języka Polskiego \\ ORCID: 0000-0002-2287-904X; e-mail: annasadowa@op.pl
}

\title{
Wybrane zjawiska słowotwórcze przymiotnika w polszczyźnie południowokresowej (na przykładzie obwodu lwowskiego)
}

\begin{abstract}
Abstrakt: Artykuł przedstawia zjawiska związane ze słowotwórstwem przymiotników w polszczyźnie południowokresowej. Podstawę materiałową analizy stanowią wyrazy rodzime i obcego pochodzenia, typowe dla polszczyzny kresowej. Omawiam sufiksy najbardziej produktywne i typowe w mowie badanych mieszkańców.
\end{abstract}

Słowa kluczowe: słowotwórstwo, przymiotnik, polszczyzna połuniowokresowa, zróżnicowanie pokoleniowe

\begin{abstract}
Selected word-building phenomena in the adjectives in Polish spoken in the southern Borderlands (example of the Lvov region). In the article, the author presents issues related to adjectives in the Polish language spoken in the south of the Borderlands. The analysis is based on words of Polish and foreign origin, typical of Polish spoken in the Borderlands. In the article, I present the most productive suffixes, typical of the speech of the surveyed population.
\end{abstract}

Keywords: word-building, adjectives, southern Borderlands of Poland, cross-section of generations

Przymiotnik w języku mówionym określa cechy i wartościuje, w gwarach natomiast - dość często w wypowiedziach informatorów - funkcję komunikowania cechy przejmują zaimki dzierżawcze lub zaimki ten, taki, jakiś. Przymiotnik nie był też przedmiotem osobnego studium w polszczyźnie południowokresowej. Dlatego moim celem jest przedstawienie wybranych zagadnień leksykalnych na przykładzie materiału z kilku miejscowości obwodu lwowskiego. Omawiam tu tylko pewną liczbę formantów oraz ich funkcję, gdyż wchodzą one w zakres tworzenia różnych kategorii słowotwórczych. Jako kontekst badawczy przyjęłam słowotwórstwo języka ogólnopolskiego oraz gwar na terenie Polski, zwłaszcza tych ulokowanych w pasie pogranicza wschodniego, jak również słowotwórstwo gwar ukraińskich, w mniejszym stopniu języka rosyjskiego i ukraińskiego. Podstawę materiałową analizy stanowią wyrazy rodzime i obcego pochodzenia, typowe dla polszczyzny kresowej.

Sytuacja polszczyzny w obwodzie lwowskim różni się od sytuacji w Polsce. Cechy systemu językowego i stopień przestrzegania normy językowej w obydwu środowiskach językowych są zupełnie odmienne. Ograniczony zakres używania języka pol- 
skiego powoduje, że polszczyzna kresowa ma status kodu środowiskowo-rodzinnego. Bliskie pokrewieństwo między tymi językami sprzyja powstawaniu licznych interferencji. Do języka mówiących wprowadzane są cechy języka ukraińskiego, w mniejszym stopniu rosyjskiego, które systemowo występują u wszystkich mówiących. Włączanie tych cech do systemu rodzimego odbywało się w ciągu wielowiekowego kontaktu z ukraińskim otoczeniem językowym. Bardzo ważne jest tu zjawisko wielojęzyczności - wykorzystywanie przez jednostkę lub grupę ludzi dwu i więcej języków w zależności od sytuacji komunikacyjnej.

Badane tereny to ziemie przygraniczne obwodu lwowskiego. Przed drugą wojną światową należały one do Polski, dziś znajdują się w granicach Ukrainy. Zamieszkująca je ludność obecnie stanowi mniejszość narodową.

Przywoływany tu materiał współczesny został pozyskany z następujących miejscowości: Mościsk (Polacy obecnie stanowią 36\% wszystkich mieszkańców miasta), Sądowa Wisznia (25\% Polaków), Rudki (25\%), Gródek Jagielloński (35\%), Sambor (23\%). W obwodzie lwowskim znajduje się największe skupisko Polaków, które zna język polski i czynnie posługuje się polszczyzną kresową ${ }^{1}$. Badani informatorzy korzystają z niej na co dzień w kontaktach domowych i sąsiedzkich. Materiał językowy pozyskiwałam m.in. drogą nagrań, pochodzi on z wcześniejszych badań ukierunkowanych na zdobycie podstawy dla rożnych celów badawczych. W ten sposób został pozyskany materiał od 420 osób, po 140 respondentów z każdego pokolenia ${ }^{2}$.

Większość materiału zebrałam drogą tradycyjnych zapisów bezpośrednio od informatorów, następnie poddałam go interpretacji semantycznej i formalnej. W analizach przedstawiam synchroniczny opis wyrazów, a materiał grupuję wokół poszczególnych formantów, określając jednocześnie charakter gramatyczny podstaw słowotwórczych omawianych formacji. Zabieg ten pozwala na uwypuklenie asocjacji wyrazu motywowanego z wyrazem motywującym w płaszczyźnie synchronicznej. Sławomir Gala pisał, że: „Ujęcie synchroniczne [...] pozwala na odniesienie rezultatów do znanych wyników w zakresie słowotwórstwa polszczyzny ogólnej i sprawia, że rezultaty opisów gwarowych są porównywalne, a podwójny wymiar opozycji prowadzi do ewentualnego wydobycia słowotwórczych wyznaczników gwarowych" (Gala 2000, 34). Pozyskane dane uporządkowałam pod względem temporalności, tj. wykorzystując podział pokoleniowy informatorów zaproponowany przez Jerzego Sierociuka. Uwzględnienie czynnika wieku pozwala poczynić kilka uwag socjolingwistycznych i ukazać wewnętrzne zróżnicowanie badanego języka oraz zmiany w nim zachodzące ${ }^{3}$.

Dorobek dotyczący opracowań słowotwórczych i leksykalnych przymiotników w gwarach polskich nie jest bogaty. Wymienię tylko kilka najważniejszych pozycji. Jedną

Polska diaspora na świece (dane szacunkowe za 2007 r.): http://wspolnotapolska.org.pl/polonia_w_ liczbach.html. Należy podkreślić, że rzeczywista liczba osób, które identyfikują się z narodowością polską, jest dużo większa, oficjalne wyniki są zaniżone ze względu na brak wystarczających środków na przeprowadzenie spisu w sposób jakościowy.

2 W badaniach wzięli udział polskojęzyczni mieszkańcy, nie brałam pod uwagę studentów uczących się w Polsce.

3 Przedziały pokoleniowe wg koncepcji Jerzego Sierociuka (2003, 134): I - urodzeni przed rokiem 1920; II - urodzeni w latach 1921-1945; III - urodzeni w latach 1946-1970; IV - urodzeni w latach 1971-1995; V - urodzeni po 1996 roku. Tu brałam pod uwagę tylko trzy pokolenia: I - urodzeni w latach 1921-1945; II - urodzeni w latach 1946-1970; III - urodzeni w latach 1971-1995. 
z nich jest artykuł Kazimierza Nitscha, w którym autor przeprowadza historycznojęzykowe rozważania nad innym i jego wariantami, a poprzez uwagi fonetyczne dochodzi do wniosku o zróżnicowaniu geograficznym. Materiał dotyczący słowotwórstwa gwarowego analizowano $\mathrm{z}$ różnych punktów widzenia: bądź to $\mathrm{w}$ postaci przeglądu formantów gwarowych, jak u Mieczysława Szymczaka (1961) i Tadeusza Malca (1976), bądź z podziałem na kategorie słowotwórcze, jak w monografiach Romana Laskowskiego (1966, 1971) czy Stefana Warchoła (1967). Władysław Cyran w 1977 roku opublikował syntezę słowotwórstwa gwar polskich - monografia ta jest najpełniejszym opracowaniem polskiego słowotwórstwa gwarowego, obejmującym cały polski obszar dialektalny. Kolejne lata XX wieku przyniosły nowe ujęcie słowotwórstwa gwarowego - derywaty uzyskiwano na podstawie badań kwestionariuszowych (pod kierunkiem Witolda Doroszewskiego), następnie mapowano poszczególne zjawiska. Prace Anny Kowalskiej (1975, 1979) i Jadwigi Symoni-Sułkowskiej (1972) przynoszą pewne zmiany metodologiczne - głównym celem staje się nie tylko przegląd formacji istniejących w gwarach, ale i odtworzenie procesu derywacji, dotarcie do genezy poszczególnych jednostek. Również Jerzy Sierociuk zaproponował nowe ujęcie problematyki słowotwórczej w gwarach (1996a, 2001). Na podstawie szczegółowych badań kwestionariuszowych przedstawił funkcjonowanie jednej kategorii w zwartym kompleksie gwarowym. Wśród najważniejszych propozycji badawczych ostatnich lat warto wymienić: 1) kwestię mapowania zjawisk słowotwórczych, a w związku z tym problem opracowania odpowiednich kwestionariuszy; 2) postulat wypracowania swoistych rozwiązań metodologicznych do opisu słowotwórstwa gwarowego; 3) plan syntetycznego opracowania polskiego słowotwórstwa gwarowego - z jednej strony według części mowy, z drugiej - według obszarów dialektalnych.

Zjawiska słowotwórcze w polszczyźnie południowokresowej nie doczekały się dotąd obszerniejszego opracowania. Uwagi o słowotwórstwie rozproszone są w nielicznych artykułach, we fragmentach monografii poszczególnych gwar polskich, pracach o języku pisarzy kresowych. Szczegółowo zajmowano się rzeczownikami, o wiele mniej przymiotnikami. Jak widać, temat przymiotnika zasługuje na szersze opracowanie.

Derywacja sufiksalna jest najczęstszym typem derywacyjnym we wszystkich dialektach polskich. Z punktu widzenia systemu słowotwórczego istotne znaczenie ma stosunkowo niewielka liczba formantów. Są to przeważnie formanty proste lub składające się z afiksów prostych, o szerokiej dystrybucji i dużym stopniu żywotności, tj. tworzące dużą liczbę formacji, produktywne, rozpowszechnione w poszczególnych gwarach.

Analizując słowotwórstwo przymiotników w polszczyźnie południowokresowej, można stwierdzić, że nie znajdziemy tu nowych formantów oprócz tych, które mają oparcie w systemie wschodniosłowiańskim. Większość przymiotników w badanej polszczyźnie ma strukturę zgodną z polskim językiem literackim, co przejawia się nie tylko na płaszczyźnie formalnej, ale też w identycznych funkcjach znaczeniowych. Dlatego też nie wymagają one bliższego omówienia. Wpływ gwar ukraińskich odcisnął jednak swoje piętno na polszczyźnie południowokresowej również w postaci formacji odbiegających od stanu, jaki jest w języku literackim. W artykule tym omówię formacje różniące się od wzorca języka ogólnopolskiego. 
O ile w zakresie fonetyki, czy szerzej fonologii, daje się zaobserwować przeciwstawienie systemowe fonetyki gwarowej fonetyce języka ogólnego, o tyle w zakresie słowotwórstwa zaobserwować możemy jedynie różnice jakościowe obydwu odmian języka. Brak tu bowiem formantów typowo gwarowych, mało też wiemy o ich geograficznym rozprzestrzenieniu czy funkcjonalności. Uwagi te odnoszą się również do omawianej polszczyzny pogranicza polsko-ukraińskiego, która generuje część formacji zgodną z gwarami ukraińskimi oraz całym obszarem wschodniosłowiańskim.

W zgromadzonym materiale znalazły się formacje, które są charakterystyczne dla polszczyzny potocznej lub zaliczane we współczesnych słownikach języka polskiego (SJPD, USJP) do przestarzałych, dawnych lub książkowych. Szereg z nich ma również formalne odpowiedniki w języku ukraińskim lub rosyjskim ${ }^{4}$. Do niniejszych badań wzięłam pod uwagę tylko formy gwarowe oraz takie, które w SJPD opatrzone są kwalifikatorami daw., przestarz. lub są notowane w innym znaczeniu. Wiele $\mathrm{z}$ tych form ma również potwierdzenie w opracowaniach dotyczących gwar rdzennej Polski ${ }^{5}$.

Wśród derywatów znalazły się także formacje genetycznie obce - o ile można je było uznać za motywowane na gruncie polszczyzny południowokresowej. Nie zajmowałam się szerzej ani pochodzeniem, ani klasyfikacją poszczególnych zapożyczeń - za Krystyną Waszakową $(1992,258)$ uznałam, że do derywatów synchronicznych można włączyć ,zapożyczenia właściwe, kalki, zapożyczenia semantyczne [...], jeśli tylko istnieją w tym samym języku odpowiednie wyrazy, które można uznać za ich podstawy słowotwórcze", wyrazy, które zostały zaadaptowane do systemu słowotwórczego polszczyzny gwarowej, to znaczy, że można je uznać za podzielne słowotwórczo i motywowane na gruncie języka-biorcy (Waszakowa 2005, 16). Zapożyczanie tego typu konstrukcji nie napotyka przeszkód w gwarach południowokresowych, jest procesem swobodnym ze względu na pokrewieństwo języków i bilingwizm.

Termin formant zapożyczony jest w publikacji pojęciem umownym - przytoczę tu słowa Bogdana Walczaka (1992, 222-230): „Właściwie nie istnieją formanty zapożyczone w ścisłym znaczeniu słowa »zapożyczony«: nie można zapożyczyć morfemu słowotwórczego. Zapożycza się wyrazy i tylko wyrazy. Dopiero po zapożyczeniu pewnej liczby wyrazów z określonym formantem [...] następuje - już całkowicie na gruncie języka zapożyczającego - proces wyabstrahowania (wydzielenia) tego morfemu i uruchomienia (»uproduktywnienia«) go jako formantu (wciąż na wyłącznym gruncie języka zapożyczającego)".

4 W celu zweryfikowania i ustalenia stopnia i zakresu funkcjonowania tychże przysłówków w językach wschodniosłowiańskich, posłużyłam się następującymi słownikami: Słownik języka polskiego pod redakcją Witolda Doroszewskiego (dalej SJPD); Stownik języka ukraińskiego (Словник украӥнської мови) pod redakcją Iwana Biłodida (dalej SUM); Słownik języka ukraińskiego (Словарь української мови) Borysa Hrinczenki (dalej Hrinczenko); Słownik języka rosyjskiego (Толковый словарь живого великорусского языка) Władimira Dala oraz Siergieja Ożegowa (dalej Dal; Ożegow), a także Słownik gwar białoruskich (Слоўнік беларускіх гаворак паўночна-заходняй Беларусі і яе пагранічча у пяиі тамах) pod redakcją Józefy Mackiewicz.

5 Korzystałam z indeksu kartoteki Stownika Gwar Polskich (KSGP).

6 Stanowisko Bogdana Walczaka (1992, 232): „Akt narodzin wyrazu (akt pojawienia się go w języku) musi być utożsamiany ze słowotwórczym aktem derywacji (w szerokim tego słowa znaczeniu). […] Niezależnie od genetycznego charakteru podstawy akt słowotwórczy zamyka się zawsze w obrębie danego języka". 
Na początek w największym skrócie przedstawiam sufiksy najbardziej produktywne i typowe w mowie badanych mieszkańców, których szerszym opracowaniem zajęłam się w innym artykule, następnie zaś omawiam kolejne formanty powszechnie występujące w mowie badanych respondentów.

Do charakterystycznych zjawisk słowotwórczych w mowie badanych respondentów, a będących wynikiem oddziaływania języka ukraińskiego, należą:

1. Sufiks -owaty, który używany jest do tworzenia przymiotników o niepełnym zakresie intensywności od podstawy przymiotnikowej i rzeczownikowej: białowaty, brudnowaty, chlodnowaty, chmarowaty, chmarnowaty, ciemnowaty, ciężkowaty, dawnowaty, durnowaty, dlugowaty, gluchowaty, karaczkowaty, prymchowaty, siniowaty, sinowaty, sirowaty, siwowaty, skucznowaty, suchowaty, sutułowaty, starowaty itp. Zachowuje on ciągłą produktywność w trzech zbadanych przedziałach pokoleniowych.

2. Formant -awy również wyraża niepełność cechy zawartej w podstawie: np.: białawy 'nieco biały', bladawy 'nieco blady', cierpkawy, kwaśnawy 'nieco kwaśny', słodkawy, żółtawy 'nieco żółty' itp. oraz w przymiotnikach z podstawą wschodniosłowiańską: -awy: hykawy 'jąkający się' (od ukr. гикати, гикавка SUM); kисzerawy 'kręcony' (od ukr. кучерi, SUM кучерявий); kulchawy, kulhawy 'kulawy' (od ukr. кульгати, SUM кульгавий); rabocieniawy 1. 'pełen zmarszczek, fałd', 2. 'pstrokaty, piegowaty' (od ukr. ряботиння 'fale na wodzie' SUM); sepetlawy, szepetlawy 'sepleniący' (od ukr. шепелявити, SUM шепелявий).

3. Formy -ozny, -azny oraz -ezny: grubiozny, grubijazny 'bardzo gruby': grubijazna baba, grubijazny chłop, szeroczazny szeroczezny, wildżozny. Formy te są przejęte z gwar ukraińskich oraz ukraińskiego języka literackiego: величезний, широчезний. $\mathrm{Na}$ badanych terenach są używane przez pokolenie średnie i młodsze.

4. Sufiks -uszczy nadaje specjalne zabarwienie emocjonalne, jest powszechny w języku rosyjskim, występuje formach imiesłowowych: bodzuszczy 'bodący', bojuszczy 'bojący się', boluszczy 'bolący', chudziuszczy, chwaluszczy 'lubiący się chwalić', ciekuszczy 'cieknący', dbajuszczy 'pilny, troskliwy', gojuszczy 'gojący', grabiuszczy 'żywy, energiczny', gryzuszczy 'gryzący', kipiuszczy 'kipiący', koluszczy 'kolący, kłujący', lepiuszczy 'lepki, kleisty': pachniuszczy 'pachący', piekuszczy 'piekący', roboczuszczy 'bardzo pracowity', sterkuszczy 'sterczący' itp., oraz w przymiotniku $\dot{z} y$ wuszczy 'żywotny, też energiczny'. Najczęściej używany on jest w mowie średniego pokolenia jako ekspresywizm, mniej u najstarszych informatorów, sporadycznie zaś u młodszych.

$\mathrm{Z}$ innych typowych dla tych terenów warto odnotować przykłady derywatów ekspresywnych tworzonych za pomocą sufiksów: -eńki (biedneńki, biednieńki 'ekspr. biedny', błaheńki 'mało istotny', choreńki 'ekspr. chory', ciemnieńki 'nieco ciemny', cienieńki 'ekspr. cienki', dobreńki, maleńki, miękieńki 'bardzo miękki', rodnieńki 'ekspr. rodzony', sinieńki 'ekspr. niebieski', siweńki, sucheńki 'ekspr. suchy', złocieńki), -ińki: (milińki 'miły’), -uni (dobruni, ładniuni, siwuni, żółciuni), -usi (biedniusi 'ekspr. biedny'; cieniusi, malusi, siwusi). Są to derywaty odprzymiotnikowe, w większości formacje wspólnotematowe, a co ważne - niemal wszystkie realizują tę samą funkcję gradacyjno-ekspresywną.

Wśród innych przykładów wykazujących znaczną produktywność w mowie respondentów wymienić trzeba formant -asty, zwłaszcza w zakresie formacji odrzeczowniko- 
wych: kandybiasty 'chudy jak szkapa': kandybiasty chtop (SUM кандиба); ceglasty, kańciasty (kańciaste portki), kraciasty (kraciasta koszula), kwiaciasty, piegasty (piegasta gemba), szpiczasty (szpiczasty nos), w formacji odczasownikowej to: wytupiasty (wytupiaste oczy). Poświadczono tu również formacje z przyrostkiem -asty, które mają odpowiedniki z przyrostkiem -aty: ceglaty, piegaty, szpiczaty, wylupiaty, poza tym formant -aty zapisałam w następujących formacjach odrzeczownikowych: czubaty, brzuchaty itp. oraz z obcą podstawą: karakaty 'krzywonogi': karakaty chłop, karakate dziecko (SUM каракатий, карачкуватий 'krzywonogi'); karapaty 'piegowaty': gemba karapata; rabociniaty 1. 'pełen zmarszczek, fałd': rabociniate czoło; 2. 'pstrokaty, piegowaty': rabociniaty chłopczyk (SUM ряботиння 'fale na wodzie'); sorokaty 'pstrokaty': bluzka sorokata, ptaszek sorokaty, krowa sorokata (SUM сорокатий dial. 'rudy, pstrokaty'); wołochaty 'włochaty': misiu wołochaty (SUM волохатий). Do tej grupy należy również zleksykalizowany przymiotnik zirkaty 'zezowaty' (una troche zirkata dziwczynka). Produktywność tego przyrostka jest powszechna u wszystkich badanych respondentów. Repartycja sufiksów -aty i -asty prowadzi do wniosku, że nie ma ona charakteru funkcjonalnego lecz leksykalny.

Przyrostki -ny, -ni są również bardzo produktywne w badanej polszczyźnie niezależnie od wieku informatorów: akuratny, akuratni 'czysty, staranny': akuratna dziewczynka, akuratny zeszyt, akuratni wzorek III, II, I (SGP w znaczeniu 'odpowiedni, należyty': Mp pd i śr, Maz wsch, Kramsk koniń, Jeleń tcz); SJPD przestarz. akuratny 'punktualny, dokładny, porządny'; SUM акуратний 'czysty, staranny, dokładny, punktualny'; budni, budny 'powszedni': budny, budni dzień, budne łachy, budni fartuch III, II, I (SGP Ubranie budnie Derewiczna radz-podl; suw PKJP II 2, 82); SUM будній; dawny, dawni 'dawny': To dawnie czasy. dawni wypadek, dawnia mąka III, II, I (SGP Siennica Różana kras; zam); SJPD dawny; SUM давніü; domaszny, domaszni 'domowy': domaszni chlib, domaszni jedzenie III, II, I (SGP n-tar ZNUJ 278, 46; Lwów); SUM домашній; drużni, drużny 'przyjazny' III, II, I (SGP My byli ras u Tarasiewicza w Warszawie, to druzny cłowiek Huszcza bial-podl; Dobrzyniewo białos; wej S I 238); SJPD daw. 'zgodny, przyjazny'; SUM дружній; krajny, krajni 'ostatni': krajni stót, krajnia dziewczyna III, II, I (SGP 'ostatni’ Orawa Sł ZNUJ 169, 246; Kresy pd); SJPD. daw. krajny; SUM крайніü; liszni, liszny 'zbędny, niepotrzebny’: liszni bilet, liszni kopijki, liszni sweter III, II, I; SUM лишній; nauczni, nauczny 'naukowy': nauczna książka, nauczne gadanie III, II, I; SJPD daw.; SUM научний; pośledni 'ostatni': pośledni kawałek III, II, I; SJPD daw.; ros. последний; SUM послідній; rańszni 'poranny’: Rańszni wstawani, rańsznim śniadaniu III, II, I (SGP Rajńsznie mleko Budy biel -podl); SUM ранішній; siny, sini 'niebieski': sinie kwiaty, pole sinie III, II, I; SJPD reg. z ros.; SUM синій; ros. синий; zadni 'tylny': zadni dźwi. zadni chłopczyk, zadni klucz III, II, I; SJPD przestarz.; SUM задній; zdatni, zdatny 'zdolny, odpowiedni, stosowny': zdatnia woda do picia, zdatna dziewczynka w szkole, ta spódnica ju nizdatnia III, II, I; SJPD przestarz.; SUM здатний.

Warto zauważyć, że alternacja sufiksów przymiotnikowych -ny, -ni występowała już w języku prasłowiańskim. Wahanie -ny, -ni notowano także w staropolszczyźnie, a dziś są tu możliwe formy fakultatywne. Marian Kucała w swoim artykule dotyczącym właśnie tego zagadnienia pisał, że sufiks - $\boldsymbol{n y}$ w znaczeniu miejscowym i czasowym jest wtórny i wyparł pierwotny sufiks -ni (Kucała 1955, 14-17). Badacz stwier- 
dził, że derywaty z sufiksem -ni mają znaczenie miejscowe - dolni, górni, zadni; czasowe - budni, ranni, przynależnościowe - paradni, chomontni. W moim materiale występuje kilka przykładów obocznych z -ny, $-\boldsymbol{n i}$, ale nie zawierają one zróżnicowania znaczeniowego, jak to było w u Mariana Kucały $(1955,14)$. Tożsamość funkcji lokalizacyjnej tych formantów oraz ich podobieństwo brzmieniowe sprawiają, że badani respondenci nie przeprowadzają ostrej granicy w ich użyciu, stąd możliwość wariantywności słowotwórczej.

Kolejną grupą przykładów są przymiotniki na $-\boldsymbol{k i}$, których pochodność jest nie zawsze uchwytna. Najczęściej wyprowadzane są one z podstaw wschodniosłowiańskich i występują niemal u wszystkich respondentów: bojki 'skory do bicia, zaczepny': bojki chłop, bojka baba III, II, I (SGP Tam jest bojkie ludzi, zaraz zachmalo jeden drugiego Degucie suw; Dobrzyniewo białos); SUM бойкий; chutki szybki, bystry, ochoczy, chętny': chutka dziewczyna, chutki dzieciak III, II, I; SUM хуткий; czutki 'czuły': córka czutka, czutki chłopak III, II, I; SUM чуткиŭ; dawki 'dławiący': dawka bulba, dawki ser III, II (SGP Dawki ser Degucie suw); SUM давкий, ros. давкий; hadki 'ohydny': hadki człowiek, hadki chrobak III, II; (SGP białos Kudz 148, Kresy); ros. гадкий; hydki 'ohydny': zachowani hydkie. hydkie żuki III, II; SUM гидкий; jedki 'dotkliwy, zjadliwy’: jedki słowa, jedki język III, II; SUM їкий, ros. едкий; jemki, jomki 1. 'pojemny': jemke torbe, jemki chołodilnik, jemka kieszenia III, II; 2. 'ostry, dobrze tnący’ III, II (SGP Piła i kosa i sikiera jomka Degucie suw; suw PJKP II 2, 85); SUM ємкий 'pojemny'; ros. ёмкий; krepki 'mocny': krepki guz, chłop krepki, krepka baba III, II (SGP Kramsk koniń); ros. крепкий; lowki 'sprytny': łowki chłopak, łowka dziewczyna III, II; SUM ловкий, ros. ловкий; merski 'ohydny': merzki robal, merzka robota, zachowani merzki III, II, I; (SUM мерзотний, мерзотно, мерзота); ros. мерзкий; hyży, hyżki 'szybki, zwinny, sprawny' III, II; SUM 'zły, zdenerwowany'; stojki 'warstwowy': placek stojki, tóżko stojkie III, II; ros. слойкий; smytki, szmytki 'szybki': szmytki chłopak, baba szmytka II; SUM швидкий; swarki 'kłótliwy': baba straszni swarka, swarki chłop III, II; SUM сваркий.

Przyrostek -liwy występuje przede wszystkim w formacjach odczasownikowych w przymiotnikach potencjalnych (skłonnościowych) zarówno w podstawach polskich, jak i wschodniosłowiańskich: hadliwy 'ohydny': hadliwe rzeczy, hadliwy człowiek, hadliwy postępek III, II (SGP Dobrzyniewo białos); ros. гадливый; kłótliwy, mrukliwy, smutliwy, spohadliwy, spogadliwy 'sentymentalny': spogadliwa kobieta, spogadliwy chłop III, II; SUM спогаd 'wspomnienie', спогадувати 'wspominać'; itp.

Przyrostek -ejszy występuje w kilku przymiotnikach odprzysłówkowych: $\boldsymbol{b u d n i e j - ~}$ szy 'powszedniejszy': budniejsza sukienka, budniejszy dzień III, II, I; SUM будній; буденний; niedzielniejszy, sobotniejszy, popoludniejszy 'popołudniowy': mleko popotudniejsze, popołudniejsze zajęcia III, II, I; SJPD ророłudniowy; SUM пополудневий; raniejszy, ranniejszy 'poranny': mliku ranniejsze, raniejszych wiadomościach III, II, I; SUM ранішній; Halina Kurkowska $(1954,108)$ pisze, że funkcje semantyczne tego typu przymiotników pokrywają się z funkcjami okoliczników czasu i miejsca. Poza tym formant -ejszy występuje również w syntetycznym sposobie tworzenia stopnia wyższego. Często w polszczyźnie południowokresowej sufiks ten wykazuje większą ekspansję i występuje po tematach supletywnych, np. ciężejszy, gorąciejszy, źlejszy. Szerszy niż w języku ogólnopolskim zakres występowania tego sufiksu zanotowano 
w gwarach biłgorajskich (Mazur, 1978, 40-41) oraz w polskich gwarach na Ukrainie (Cechosz, 2001, 99).

Polszczyzna południowokresowa stanowi system składający się z wielu warstw, w którym trzeba uwzględniać wpływ obcy oraz zróżnicowanie wiekowe użytkowników gwary, główny zaś trzon przymiotników stanowią formacje wspólne z językiem ogólnym. W wyniku analizy słowotwórczej przymiotników widzimy, że funkcje semantyczne formantów nie wykazują odrębności, pokrywają się na ogół funkcjami znanymi nam z języka literackiego, a słowotwórstwo gwarowe w zakresie przymiotników nie dysponuje formantami od niego odmiennymi. Cechą zaś typową dla omawianej polszczyzny jest wielka produktywność i zakres występowania poszczególnych formantów, a także różna od znanej z języka ogólnego dystrybucja niektórych z nich.

Analizowana próba ujawniła także różnice międzypokoleniowe. Wpływy wschodniosłowiańskie (formanty obce oraz podstawy ruskie) ujawniają się w pokoleniach średnim i młodszym, żyjących w czasie, gdy ekspansja tych języków była najsilniejsza, stąd wiele takich przykładów, jak: dawki 'dławiący', hadki, hydki, hadliwy 'ohydny', jedki 'dotkliwy, zjadliwy', jemki, jomki, towki 'sprytny', hyży, hyżki 'szybki, zwinny, sprawny', krepki 'mocny', stojki 'warstwowy', swarki 'kłótliwy', spohadliwy, spogadliwy 'sentymentalny'. W pokoleniu średnim zanotowałam jedynie przymiotnik smytki, szmytki 'szybki'. Przykładów tych nie jest wiele, jednak pokazują one okres największego wpływu języków sąsiednich.

Badając system słowotwórczy należy zwrócić uwagę na istotny fakt, jakim jest ekspresywność. Ta sama podstawa przymiotnikowa może wchodzić w kontakt z wieloma formantami, które intensyfikują cechę przymiotnika. Występuje tu liczna grupa formacji z nacechowaniem ekspresywnym, uczuciowym. Ekspresywność w gwarze odznacza się o wiele szerszym zakresem niż w języku ogólnopolskim.

\section{Wykaz skrótów nazw powiatów i innych określeń geograficznych}

Skróty geograficzne są zgodne z zasadami redakcyjnymi Słownika gwar polskich (SGP).

$$
\begin{aligned}
& \text { bial-podl - bialski (Biała Podlaska) } \\
& \text { białos - białostocki (Białystok) } \\
& \text { biel-podl - bielski (Bielsk Podlaski) } \\
& \text { koniń - koniński (Konin) } \\
& \text { kras - krasnostawski (Krasny Staw) } \\
& \text { Maz - Mazowsze } \\
& \text { Mp - Małopolska } \\
& \text { n-tar - nowotarski (Nowy Targ) } \\
& \text { pd - południowy } \\
& \text { pd-wsch - południowo-wschodni } \\
& \text { pd-zach - południowo-zachodni } \\
& \text { radz-podl - radzyński (Radzyń Podlaski) } \\
& \text { siem - siemiatycki (Siemiatycze) } \\
& \text { suw - suwalski (Suwałki) } \\
& \text { tcz - tczewski (Tczew) } \\
& \text { wej - wejherowski (Wejherowo) }
\end{aligned}
$$


wsch - wschodni

zam - zamojski (Zamość)

\section{Wykaz źródeł materiału gwarowego}

K, Karłowicz J. (1900-1911), Słownik gwar polskich, t. I-VI, Kraków.

KSGP, kartoteka Stownika gwar polskich, http://rcin.org.pl//publication/37156 (dostęp: 21.10.2016).

Kudz, Rembiszewska D.K. (2007), Słownik dialektu knyszyńskiego Czesława Kudzinowskiego, Łomża.

MAGP, Mały atlas gwar polskich, oprac. przez Pracownię Atlasu i Słownika Gwar Polskich Zakładu Językoznawstwa PAN w Krakowie, t. I-II pod kier. K. Nitscha, t. III-XIII pod kier. Mieczysława Karasia, Wrocław 1957-1970.

PKJP II 2, Zdancewicz T. (1966), Wplywy białoruskie $w$ polskich gwarach pod Sejnami, Prace Komisji Językoznawczej Poznańskiego Towarzystwa Przyjaciół Nauk, Poznań.

RamŚs, Ramułt S. (1930), Gwara ślemieńska, t. I: Słownik, do druku przygotował i wstępem opatrzył E. Klich, Poznań.

S, Sychta B. (1967, 1968, 1969, 1970, 1972, 1973, 1976), Stownik gwar kaszubskich na tle kultury ludowej, t. I: $A-G$, t. II: $H-L$, t. III: $E-O$, t. IV: $P-\check{R}, \mathrm{t} . \mathrm{V}: S-T$, t. VI: U-Ž, t. VII: Suplement, Wrocław-Warszawa-Kraków (- Gdańsk).

SGOWM, Stownik gwar Ostródzkiego, Warmii i Mazur. Zeszyt próbny, t. I: A-Ć, pod red. Z. Stamirowskiej, Wrocław-Warszawa-Kraków-Gdańsk-Lódź 1987; t. II: $D-G$, pod red. Z. Stamirowskiej, Wrocław-Warszawa-Kraków 1991; t. III: $H-K$, pod red. Z. Stamirowskiej i H. Perzowej, Warszawa-Kraków 1993; t. IV: $L-N$, pod red. H. Perzowej i D. Kołodziejczykowej, Warszawa-Kraków 2002; t. V: $O-O$, pod red. H. Perzowej i D. Kołodziejczykowej, Warszawa-Kraków 2006.

SGP, Słownik gwar polskich, oprac. przez Zakład Dialektologii Instytutu Języka Polskiego PAN w Krakowie, t. 1 pod kier. M. Karasia, t. 2-5 pod kier. J. Reichana, t. 6-7, pod kier. J. Okoniowej, Kraków 1982-2007.

ZNUJ 169 Zaręba A. (1968), Polskie teksty gwarowe z Orawy na Słowacji.

ZNUJ 278, Bubak J. (1972), Spiskie teksty gwarowe z obszaru Polski.

\section{Literatura}

Buczyński M. (1967), Wschodniosłowiańskie wplywy językowe w gwarze wsi Huszcza powiat Biała Podlaska, „Annales Universitatis Mariae Curie-Skłodowska. Sectio F, Nauki Filozoficzne i Humanistyczne", 22, s. 223-256.

Cechosz I. (2001), Polska gwara Oleszkowiec na Podolu. Fleksja imienna i werbalna, Kraków.

Chludzińska-Świątecka J. (1956), Przymiotniki w gwarach Warmii i Mazur. (Uwagi słowotwórczosemantyczne), „Poradnik Językowy”, 1, s. 21-27.

Cyran W. (1977), Tendencje słowotwórcze w gwarach polskich, Łódź. 
Cyran W. (1981), Stowotwórstwo historyczne a stowotwórstwo wspótczesne i stowotwórstwo gwarowe, Łódź.

Czyżewski F. (1976), Gwara (morfologia i składnia) osady Łomazy, „Annales Universitatis Mariae Curie-Skłodowska. Sectio F, Humaniora", 31, s. 357-370.

Dal, Dal W.I. (1903-1909), Tołkowyj słowar' żywogo wielikorusskogo jazyka, t. 1-4, SanktPieterburg-Moskwa.

Gala S. (2000), Stowotwórstwo gwarowe a stowotwórstwo polszczyzny ogólnej, „Rozprawy Komisji Językowej Łódzkiego Towarzystwa Naukowego", t. XLV, s. 28-36.

Gałecki Z., 1996, Z metodologii badań polsko-ukraińskiego pogranicza językowego na Podlasiu (o dawnej granicy etnicznej i językowej), Studia Dialektologiczne, t. I, pod red. B. Dunaja i J. Reichana, Kraków, s. 97-103.

Jędrzejewska M., Stieber Z. (1951), Przedrostki stopnia najwyższego na- $i$ naj- $w$ dawnej polszczyźnie $i w$ dzisiejszych gwarach, „Język Polski”, 31, s. 77-85.

Jodłowski S. (1949), O przysłówkach, partykułach i im pokrewnych częściach mowy, „Język Polski”, XIX 1, s. 97-106.

Karaś M. (1964), Z problematyki słowotwórstwa gwarowego. (Formacje przymiotnikowe), „Prace Filologiczne", XVIII, cz. 3, s. 153-162.

Kostecka-Sadowa A. (2013), Wybrane tendencje słowotwórcze w polszczyźnie południowokresowej na przykładzie Mościsk i okolic, „Socjolingwistyka”, 27, s. 153-161.

Kość J. (2000), Archaizmy a interferencje w strefie polsko-ukraińskich kontaktów językowych, „Slavia Orientalis”, 49, z. 3, s. 451-462.

Kowalska A. (1975, 1979), Zróżnicowanie słowotwórcze gwar Mazowsza i Podlasia. Rzeczownik, t. 1: Atlas, cz. 1: Mapy 1-100, cz. 2: Wykazy i komentarze do map 1-100, t. 2: Atlas, cz. 1: Mapy 101-200, cz. 2: Wykazy i komentarze do map 101-200, Wrocław.

Kucała M. (1955), Znaczenie i zasięg przymiotników na -ni (przedni, letni), „Język Polski”, XXXV, s. 8-26.

Kurkowska H. (1954), Budowa słowotwórcza przymiotników polskich, Wrocław.

Kurkowska H., Skorupka S. (2001), Stylistyka polska: zarys, Warszawa.

Kurzowa Z. (1983), Polszczyzna Lwowa i kresów poludniowo-wschodnich do 1939 roku, Warszawa-Kraków.

Laskowski R. (1966), Derywacja rzeczowników w dialektach laskich, cz. 1: Abstracta, collectiva, deminutiva, augmentativa, Wrocław.

Laskowski R. (1971), Derywacja rzeczowników w dialektach laskich. Rzeczowniki z formatem w funkcji przedmiotowej, Wrocław.

Malec T. (1976), Budowa słowotwórcza rzeczowników i przymiotników w gwarze wsi Rachanie pod Tomaszowem Lubelskim, Prace Językoznawcze PAN 79, Wrocław

Mazur J. (19780, Gwary okolic Biłgoraja, cz. II: Fleksja, Wrocław-Warszawa-Kraków-Gdańsk.

Nitsch K. (1936), Inny i jego odmiany, „Język Polski”, XXI, z. 3, s. 71-75.

Nowowiejski B. (1989), Mowa mieszkańców Sokótki w woj. białostockim, [w:] Polszczyzna pótnocno-wschodnia. Metodologia badań językowych, red. B. Falińska, Wrocław, s. 87-96.

Nowowiejski B. (2010), Z życia wschodnich slawizmów leksykalnych $w$ mowie miast $i$ miasteczek Białostocczyzny, [w:] B. Nowowiejski, Z zagadnień kontaktów językowych, Białystok, s. 215-228. 
Orłowicz M. (1919), Ilustrowany przewodnik po Galicyi, Bukowinie, Spiszu, Orawie i Ślasku Cieszyńskim, Lwów.

Ożegow, Ożegow S.I. (red.) N.J. Szwedowa (1992), Tołkowyj stowar' russkogo jazyka, Moskwa.

Reichan J. (1996), Problem syntetycznego ujęcia polskiego stowotwórstwa gwarowego. Zarys koncepcji, Studia Dialektologiczne, t. I, red. B. Dunaj, J. Reichan, Kraków, s. 191-195.

SBH, Mackiewicz J.F. (red.) (1979-1986), Stounik biełaruskich haworak paunoczna-zachodniaj Biełarusi i jaje pahraniczcza u piaci tamach, t. 1-5, Minsk.

Sierociuk J. (1992), Oboczność podstaw stowotwórczych i poświadczenia negatywne w badaniach słowotwórstwa gwarowego, Rozprawy Komisji Językowej Łódzkiego Towarzystwa Naukowego, t. XXXVI, s. 169-181.

Sierociuk J. (1996a) Wybrane problemy metodologii badań i opisu stowotwórstwa gwarowego, Studia Dialektologiczne, t. I, red. B. Dunaj, J. Reichan, Kraków, s. 197-205.

Sierociuk J. (1996b), Z zagadnień produktywności formantów gwarowych, Poznańskie Spotkania Językoznawcze, t. I, pod red. Z. Krążyńskiej i Z. Zagórskiego, Poznań. s. 59-65.

Sierociuk J. (1999), Formanty wschodniopolskie w gwarach Wielkopolski? Poznańskie Spotkania Językoznawcze, t. V, pod red. Z. Krążyńskiej i Z. Zagórskiego, Poznań. s. 73-79.

Sierociuk J. (2001), Założenia metodologiczne badań słowotwórstwo gwarowe, Gwary Dziś, t. I, pod red. J. Sierociuka, Poznań, s. 153-160.

Sierociuk J. (2003), Założenia metodologiczne badań języka wsi, Poznańskie Spotkania Językoznawcze, t. XI, pod red. Z. Krążyńskiej i Z. Zagórskiego, Poznań, s. 131-136.

SJPD, Doroszewski W. (red.) (1958-1968), Stownik języka polskiego, t. 1-11, Warszawa.

Skorowidz miejscowości Rzeczypospolitej Polskiej opracowany na podstawie wyników Pierwszego Powszechnego Spisu Ludności z dnia 30 września 1921 r. i innych źródet urzędowych, t. 13: Województwo lwowskie, Warszawa 1924.

SUM, Biłodid I.K. (red.) (1970-1980), Stownyk ukrajins'koji mowy, t. 1-11, Kyjiw, http:/lcorp. ulif.org.ua/dictua/ (dostęp: 10.02.2107).

Symoni-Sułkowska J. (1972), Zróżnicowanie słowotwórcze i leksykalne nazw z zakresu transportu $i$ komunikacji w gwarach polskich, Wrocław.

Walczak B. (1992), Granica między jednostkami leksykalnymi rodzimymi i obcego pochodzenia, [w:] Opisać słowa, Materiały ogólnopolskiej sesji naukowej w rocznicę śmierci Profesor Danuty Buttler „Teoretyczne i metodologiczne zagadnienia leksykologii”, Warszawa 4-5 marca 1992 r., pod red. A. Markowskiego, Warszawa.

Walczak B. (1999), Zapożyczenia leksykalne: teoria i metodologia badań, [w:] Polszczyzna pótnocno-wschodnia, t. II, pod red. B. Nowowiejskiego, Białystok.

Warchoł S. (1967), Gwary dawnej Ziemi Stężyckiej, Wrocław.

Waszakowa K. (1992), Zapożyczenia jako przedmiot badań stowotwórstwa synchronicznego, Z Polskich Studiów Slawistycznych, seria VIII: Językoznawstwo, Warszawa.

Waszakowa K. (2005), Przejawy internacjonalizacji w słowotwórstwie wspótczesnej polszczyzny, Warszawa.

Zaręba A. (1957), Uwagi o geografii słowotwórczej, „Biuletyn Polskiego Towarzystwa Językoznawczego", XVI, s. 165-174.

Zdancewicz T. (1966), Wpływy białoruskie w polskich gwarach pod Sejnami, Poznań.

Zdancewicz T. (1980), Mazurzace gwary suwalskie, Poznań. 
